DOI: $10.14720 /$ aas.2016.107.1.18

Agrovoc descriptors: malus domestica; phenolic compounds; defence mechanisms; fungal diseases; bacterioses; phenols

Agris category code: F60, h01

\title{
Research on the involment of phenoloics in the defence of horticultural plants
}

\author{
Ana SLATNAR ${ }^{1}$, Maja MIKULIČ-PETKOVŠEK ${ }^{1}$, Robert VEBERIČ ${ }^{2}$ and Franci ŠTAMPAR ${ }^{2}$
}

Received December 22, 2015; accepted February 20, 2016.

Delo je prispelo 22. decembra 2015, sprejeto 20. februarja 2016.

\begin{abstract}
Phenolic compounds are not directly involved in the primary metabolism of plants but possess a number of important roles: (1) serving as attractants for pollinators and various animals, involved in the transfer of seeds, (2) plant protection from herbivores and against pathogen infection, (3) defining plantplant relationships and the symbiosis between plants and microbes. The present review of our research work stresses the role of phenolic compounds in the defense mechanism against different fungi and bacteria. It has been established, that the content of phenolics is greatly affected by the infection with pathogenic organisms. Studies on several horticultural plants have demonstrated that the response to infection differs among the analyzed plant species. Generally, an increase of phenolic compounds can be expected in tissues near the infection site. The comparison of healthy and infected tissue reflects an increase of phenolics in infected tissues. Higher levels of all analyzed phenolic groups have been measured in the latter, with the exception of the anthocyanins. Based on the findings of many-year research studies, it can be concluded that phenolic compounds are involved in the plant defense mechanisms, but the response varies among species.
\end{abstract}

Key words: Malus domestica Borkh., fruits, vegetables, infection by fungy and bacteria, phenolics

\section{IZVLEČEK}

\author{
RAZISKOVANJE VKLJUČEVANJA FENOLOV V \\ OBRAMBNE REAKCIJE HORTIKULTURNIH \\ RASTLIN
}

Fenolne snovi so spojine, ki niso neposredno vključene $\mathrm{v}$ osnovni metabolizem rastlin, vendar imajo $\mathrm{v}$ njih številne druge pomembne vloge: (1) služijo kot atraktanti za opraševalce in druge živali, ki so vključene v prenos semen, (2) ščitijo rastline pred herbivori in pred okužbo $z$ glivami in mikrobi, (3) sodelujejo pri kompeticiji rastlina-rastlina in simbiozi rastline $\mathrm{z}$ glivami in bakterijami. $\mathrm{V}$ pregledu naših raziskav $\mathrm{z}$ vidika vloge fenolnih snovi $\mathrm{v}$ obrambnem mehanizmu pred različnimi glivami in bakterijami lahko poudarimo, da so fenoli z gotovostjo ena od snovi, s katerimi se rastline odzivajo na okužbo s patogeni. Študije na različnih hortikulturnih rastlinah so pokazale, da odziv na okužbo ni enak pri različnih rastlinskih vrstah. Največkrat prihaja do povečanja koncentracij fenolnih snovi $\mathrm{v}$ okolici okužbe. Primerjava zdravega in okuženega tkiva $\mathrm{v}$ večini primerov kaže povečanje vsebnosti fenolov $\mathrm{v}$ okuženih tkivih pri vseh analiziranih skupinah fenolnih snovi, $\mathrm{z}$ izjemo skupine antocianov. Na podlagi povzetkov večletnih raziskav, ki so strnjene $\mathrm{v}$ delu, lahko podamo zaključek, da so fenolne snovi vključene $\mathrm{v}$ proces obrambe, vendar je odziv rastlin vrstno specifičen.

Ključne besede: Malus domestica Borkh., sadje, zelenjava, okužba z glivami in bakterijami, fenoli

\section{INTRODUCTION}

Plant phenolics are secondary metabolites that encompass several classes of structurally diverse products arising from the shikimatephenylpropanoid pathways. Plants use phenolic compounds for pigmentation, growth, reproduction, resistance to pathogens and many other functions (Lattanzio et al., 2006). Polyphenols protect plants against adverse factors

1 assistant professor of Horticulture, University of Ljubljana, Biotechnical faculty, Agronomy department, Chair for Fruit, Wine and Vegetable Growing, Jamnikarjeva 101, SI-1000 Ljubljana, Slovenia

2 professor of Horticulture, University of Ljubljana, Biotechnical faculty, Agronomy department, Chair for Fruit, Wine and Vegetable Growing, Jamnikarjeva 101, SI-1000 Ljubljana, Slovenia 
that threaten their survival in an unfavorable environment, such as drought, UV radiation, infection or physical damage. The presence of phenolic metabolites in plants is greatly influenced by environmental conditions and is also genetically controlled (Lattanzio et al., 2008). Therefore, they represent adaptive characters that have been subjected to natural selection during evolution (Lattanzio et al., 2006; Treutter, 2006; Russell et al., 2009).

Phenolic compounds possess antimicrobial properties against fungi, bacteria and viruses (Martini et al., 2009). As a result of microbial attack, phenolics may accumulate as inducible low-molecular-weight compounds, which can be post-inflectional or constitutive (Stack, 1997). Preformed antifungal phenolics belong to different classes like simple phenols, phenolic acids, flavonols and dihydrochalcones. If pre-formed antifungal phenolics are not sufficient to stop the development of the infection process, plant cells usually respond by increasing the level of antifungal phenols at the infection site or synthesize specific defense compounds (phytoalexins). In the first case, phenolics can rapidly accumulate upon attack, although they may already be present at low concentrations in the plant. In the second case, these compounds are already present in healthy tissues at concentrations high enough for defense, either as free compounds or in their conjugated forms, from which they are released after the attack (Strack, 1997). It has been shown that some hydroxycinnamic acids, flavanols (epicatechin, procyanidin B1, catechin) and dihydrochalcones may be involved in the defense mechanism of apple leaves against the scab fungus Venturia inaequalis (Cooke) G. Winter (MikuličPetkovšek et al., 2009; Slatnar et al., 2012).

In general, an increased level of phenols was observed in infected leaf tissues compared to healthy tissues (Mikulič-Petkovšek et al., 2011). Phenolic compounds slow down fungal growth, reacting with proteins and causing a loss of enzymatic function. Moreover, they restrict the viability of pathogens, and can be deposited inside the cell wall as an important first line of defense against fungal penetration and infection (Schwalb and Feucht, 1999).

The aim of this paper is to illustrate the response to biotic stress (specifically, fungal attack) in different horticultural plants. With knowledge of that response we could develop natural friendly cultivation methods and assist the plant to defend itself.

\section{MATERIALS AND METHODS}

The study was performed on different plants: apple (Malus domestica Borkh.), strawberry (Fragaria $x$ ananassa Duch.), green bean (Phaseolus vulgaris L.), raspberry (Rubus idaeus L.), and walnut (Juglans nigra L.). Different parts of the tissue (fruits or canes in different developmental stages) infected with different causative agents (Venturia inaequalis (Cooke) G. Winter, Xanthomonas arboricola pv. juglandis (Pierce) Dye, Didymella applanata (Niessl) Sacc., Leptosphaeria coniothyrium (Fuckel) Sacc., Colletotrichum nymphaeae (Pass.) Aa, Colletotrichum lindemuthianum (Sacc. \& Magnus) Briosi \& Cavara) were sampled from plants growing in the University experimental orchard/field in Ljubljana (Mikulič-Petkovšek et al., 2013, 2014; Slatnar et al., 2010, 2012; Solar et al., 2012).
The selected tissue was differentiated to infected and healthy. Different numbers of replicates for each part of sampled tissue were performed for determination of phenolic compounds (MikuličPetkovšek et al., 2013, 2014; Slatnar et al., 2010, 2012; Solar et al., 2012). Samples were immediately shock-frozen in liquid nitrogen and stored at $-80{ }^{\circ} \mathrm{C}$ until analysis of the samples.

Extraction with some modification was carried out as described by our previous reports (MikuličPetkovšek et al., 2013, 2014; Slatnar et al., 2010, 2012; Solar et al., 2012). The powdered samples were extracted with methanol containing $1 \%$ 2,6di-tert-butyl-4-methylphenol (BHT) and homogenized with the T-25 Ultra-Turrax (IkaLabortechnik, Staufen, Germany). BHT was added to the samples to prevent oxidation during the extraction. 
Samples were placed in a cooled ultrasonic bath $\left(0{ }^{\circ} \mathrm{C}\right)$ for $1 \mathrm{~h}$; then they were centrifuged and the supernatants were filtered through a Chromafil A045/25 polyamide filter produced by MachereyNagel (Düren, Germany). The high performance liquid chromatography (HPLC) analysis was performed on a Surveyor HPLC system with PDA detector (Thermo Finnigan, San Jose, CA, USA). The column was a Gemini C18 $(150 \times 4.6 \mathrm{~mm}$, $3 \mu \mathrm{m}$; Phenomenex, CA, USA) operated at $25^{\circ} \mathrm{C}$.

The elution solvents, HPLC conditions and identification of phenolic compounds were the same as described by previous reports (MikuličPetkovšek et al., 2013, 2014; Slatnar et al., 2010, 2012; Solar et al., 2012). The concentrations of phenolic compounds were calculated from the peak areas of samples and the corresponding standards.

The data were analyzed using the Statgraphics Plus 4.0 (Manugistics, Inc., Rockville, MD, USA). Data from the chemical analyses were tested for any differences between treatments using one-way analysis of variance (ANOVA). The means and standard errors of the means (mean $\pm \mathrm{SE}$ ) are also reported.

\section{RESULTS AND DISCUSSION}

It has been determined that hydroxycinnamic acid (HCA) derivatives play a major role in plant resistance and exhibit a fungitoxic effect against different pathogens, because they inhibit the growth and sporulation of fungi (Sammi et al., 2009; Chardonnet et al., 2003). The highest content of HCA in apple peel was measured in the scab symptomatic spot, followed by the tissue around the spot (Table 1). This is probably a result of stress conditions in the plant, which are caused by the presence of Venturia inaequalis. Increased amounts of HCA were also reported by MikuličPetkovšek et al. (2009) and Leser and Treutter (2005) because of stress conditions. The plant response to artificial inoculation with the Colletotrichum lindemuthianum has been monitored in green bean pods and the content levels of HCA increased in both bordering and infected tissue (Table 1). The increase of all analyzed HCA after the Xanthomonas arboricola pv. juglandis (Xaj) infection (Table 2) may also be a consequence of stimulated PAL activity, as described in apple fruits infected with $V$. inaequalis by Slatnar et al. (2010). Significantly lower content (10-30\% decrease) of total hydroxycinnamic acid derivatives were detected in infected raspberry canes compared to healthy ones. Other research studies also confirmed a decrease of cinnamic acid derivatives after infection (Maurya et al., 2007; Rusjan et al., 2012), as observed in our study in raspberry canes.
The analysis of different bean pod parts (healthy, infected (Colletotrichum lindemuthianum) and bordering tissue) revealed a significant increase of total flavanols induced by the fungal infection (Table 1). In bordering tissue and lesion the content of flavanols was 3-10 folds higher compared to healthy tissue. Higher levels of individual procyanidin forms and epicatechin in infected strawberry fruit have also caused a 2.2-2.4-fold higher level of total flavanols compared to healthy fruit (Table 2). In green walnut husks higher accumulation has been observed in tissue infected with Xaj (Table 2). These results are in line with other studies (Mikulič-Petkovšek et al., 2011; Slatnar et al., 2012), which report a higher content of flavanols in plant tissue triggered by different pathogen infections. According to some studies, an increased synthesis and accumulation of flavanols in plant tissues could be linked to their higher resistance (Leser and Treutter, 2005). The role of catechin in the plants pathogen defense might be their interaction with proteins and inhibition of the enzymes secreted by pathogenic fungi (Bors and Michel, 2002). It has been suggested that a rapid accumulation of monomeric and polymeric flavanols at the infection site stops further dissemination of the pathogens (Treutter and Feucht 1990; Mayr et al., 1997). 
Table 1: The content of different phenolic groups in healthy and infected French green bean pods and apple peel

\begin{tabular}{lccc|rcc}
\hline & \multicolumn{2}{c|}{ French green bean pods $(\mu \mathrm{g} / \mathrm{g} \mathrm{DW})$} & \multicolumn{3}{c}{ apple peel $(\mathrm{mg} / \mathrm{kg}$ FW) } \\
& \multicolumn{1}{c}{ healthy } & \multicolumn{1}{c}{ lesion } & boundary zone & healthy & \multicolumn{2}{c}{ spot } \\
\hline Hydroxycinnamic acids & $203.7 \pm 16.7 \mathrm{a} *$ & $379.9 \pm 46.4 \mathrm{~b}$ & $899.1 \pm 81.97 \mathrm{c}$ & $196.4 \pm 20.3 \mathrm{a} *$ & $349.0 \pm 37.1 \mathrm{~b}$ & $964.5 \pm 38.2 \mathrm{c}$ \\
Flavanols & $1347.0 \pm 159.4 \mathrm{a}$ & $4348.3 \pm 659.5 \mathrm{a}$ & $14308.7 \pm 1360.18 \mathrm{~b}$ & $863.9 \pm 58.8 \mathrm{a}$ & $2594.6 \pm 98.0 \mathrm{c}$ & $1161.0 \pm 102.3 \mathrm{~b}$ \\
Flavonols & $377.5 \pm 61.3 \mathrm{a}$ & $477.0 \pm 86.2 \mathrm{a}$ & $1039.9 \pm 101.56 \mathrm{~b}$ & $3276.6 \pm 456.0 \mathrm{a}$ & $2769.1 \pm 91.8 \mathrm{a}$ & $2319.5 \pm 100.0 \mathrm{a}$ \\
Dihydrochalcones & $25.2 \pm 4.8 \mathrm{a}$ & $45.0 \pm 5.1 \mathrm{a}$ & $179.5 \pm 22.62 \mathrm{~b}$ & $534.3 \pm 62.2 \mathrm{a}$ & $1254.9 \pm 60.4 \mathrm{~b}$ & $831.6 \pm 17.1 \mathrm{c}$ \\
\hline
\end{tabular}

DW - dry weight; FW - fresh weight

*Different letters denote statistically significant differences among treatments for each individual phenolic group and plant.

Scab symptomatic spot contained more than twofold higher levels of total flavonols compared to healthy apple peel (Table 1). The infection with C. lindemuthianum caused an increase of total flavonols in bordering and infected tissue: a 1.33.3 fold higher content was measured compared to healthy bean tissue (Table 1). The results of our study indicate that infected strawberry fruit contained significantly higher levels of flavonols (Table 2). Similar to other analyzed phenols the infection with the Xaj bacteria caused an increased synthesis of flavonols (Table 2). A decrease of total quercetin glycosides has been measured in infected raspberry cane tissue, which could potentially occur at the expense of an increase in flavanol levels in infected tissue, as quercetin glycosides are precursors for the synthesis of mono- and poly-meric flavanols and are intensively consumed in the phenylpropanoid pathway. The accumulation of high flavonol amounts in the apple skin is probably related to the physiological function of UV protection but may also be related to pathogen defense (Dixon and Paiva, 1995). Shirley (1996) reported that flavonols play an essential role in plant defense against bacterial and viral pathogens, as they have been known to induce the virulence genes of Agrobacterium tumefaciens Smith \& Townsend. Moreover, an increase in flavonoids due to the infection with pathogens has been reported in other fruit species (Mikulič-Petkovšek et al., 2008). In response to scab infection, cells surrounding the infection site accumulate flavonols, forming a barrier to the progression of the infection (Feuch and Treutter, 1998). Rusjan et al. (2012) on contrary reported that infection with bois noir phytoplasma caused a statistically significant decrease in flavonol content, probably due to formation of other compounds competing for the same substrate.

Our study on green bean pods indicated that the infected lesion and bordering tissue contained higher levels of total dihydrochalcones compared to healthy bean pod tissue (Table 1). Statistically higher content of dihydrochalcones has also been observed in the apple scab symptomatic spot and in the surrounding tissue compared to the healthy apple peel (Table 1). An involvement of dihydrochalcones in pathogen defense is frequently disputed because all apple cultivars generally contain high levels of phloridzin. However, differences in disease resistance could be determined by divergent local accumulation or by differences in the speed of the oxidation cascade (hypersensitive reaction) after pathogen attack rather than the actual amount of phloridzin present in the plant (Gosch et al., 2010). MacHardy (1996) and Hrazdina et al. (1997) reported that phloridzin produced in apple in response to Venturia inaequalis, accumulated around the infection sites and assumed that the corresponding aglycone phloretin, which is generated by plant glucosidases after pathogen attack, negatively affects the pathogen growth. The hypothesis that the aglycone rather than the 2'-O-glucoside is involved in the pathogen defense has further been confirmed by Slatnar et al. (2010) who determined a decrease of UDP-glucose: phloretin 2'-O-glycosyltransferase activity in the scab symptomatic spot compared to healthy tissue, which contrasted with the observed increase of other flavonoid enzymes. 
Table 2: The content of different phenolic groups in healthy and infected raspberry canes, green walnut husks or strawberry fruit

\begin{tabular}{lcc}
\hline & raspberry canes $(\mathrm{mg} / \mathrm{kg} \mathrm{FW})$ \\
& healthy & infected \\
Hydroxycinnamic acids & $90.1 \pm 4.1 \mathrm{~b}^{*}$ & $67.5 \pm 3.3 \mathrm{a}$ \\
Flavanols & $8906.0 \pm 635.6 \mathrm{a}$ & $15093.4 \pm 760.9 \mathrm{~b}$ \\
Flavonols & $735.4 \pm 65.9 \mathrm{~b}$ & $229.9 \pm 34.4 \mathrm{a}$ \\
Ellagic acid derivatives & $362.7 \pm 28.3 \mathrm{~b}$ & $310.8 \pm 12.3 \mathrm{a}$ \\
& green walnut husks $(\mathrm{mg} / \mathrm{kg} \mathrm{FW})$ \\
& healthy & infected \\
Hydroxycinnamic acids & $499.0 \pm 4.1 \mathrm{a}^{*}$ & $1912.5 \pm 63.3 \mathrm{~b}$ \\
Flavanols & $172.9 \pm 15.6 \mathrm{a}$ & $2909.4 \pm 150.9 \mathrm{~b}$ \\
Flavonols & $192.2 \pm 12.9 \mathrm{a}$ & $459.1 \pm 34.4 \mathrm{~b}$ \\
& strawberry fruit $(\mathrm{mg} / \mathrm{kg} \mathrm{FW})$ \\
& healthy & infected \\
Ellagic acid derivatives & $37.0 \pm 2.9 \mathrm{a}$ & $65.9 \pm 4.5 \mathrm{~b}$ \\
Flavanols & $559.9 \pm 50.8 \mathrm{a}$ & $1237.2 \pm 75.9 \mathrm{~b}$ \\
Flavonols & $19.0 \pm 0.2 \mathrm{a}$ & $34.9 \pm 3.3 \mathrm{~b}$ \\
Anthocyanins & $373.3 \pm 27.5 \mathrm{~b}$ & $308.1 \pm 36.9 \mathrm{a}$ \\
\hline
\end{tabular}

FW - fresh weight

*Different letters denote statistically significant differences between treatments for each individual phenolic group and plant.

Results indicate a significantly higher content of ellagic acid derivatives in healthy raspberry canes compared to the infected tissue (Table 2). Our results on strawberry fruit demonstrate that the infection causes an increase of ellagic acid derivatives (Table 2). Higher content of ellagic acid derivatives can be ascribed to modifications in the metabolic processes within the plant as several studies report increased accumulation of specific compounds as a defense mechanism to stress. With up-regulation of certain metabolic processes, the plant aims to stop or at least reduce the growth of the pathogen, and ellagic acid and its derivatives are known to possess antimicrobial activity (Zhou et al., 2007; Quare et al., 2012).

\section{CONCLUSIONS}

Although a large number of phenolics from different metabolic groups has been identified and quantified in various plants the resistance mechanisms cannot solely be explained by plant's phenolic profiles. Results support the hypothesis that phenolic compounds play an important role in host defence in infected tissue and that the mechanism of resistance may be influenced by responses linked to the host-pathogen interaction. However, it is obvious that the defense reaction is not enough to overcome the disease. In addition to polyphenols, other biochemical compounds are potentially involved in defense response. Additional studies may help clarify the precise mechanisms, processes, and important resistance indicators within the plants, which take place after the pathogen attack. Specific studies are of great importance to help minimize the negative effects of fungal diseases in fruit/vegetable production which cause large yield losses due to their fast spread, ineffective chemical treatments, and long withdrawal periods of fungicides. 


\section{ACKNOWLEDGEMENTS}

This work is part of program Horticulture No. P40013-0481, funded by the Slovenian Research Agency (ARRS).

\section{REFERENCES}

Bors W. and Michel C., 2002: Chemistry of the antioxidant effect of polyphenols. Annals of the New York Academy of Sciences 957: 57-69. DOI: 10.1111/j.1749-6632.2002.tb02905.x

Chardonnet, C.O., Charron, C.S., Sams, C.E. and Conway, W.S., 2003: Chemical changes in the cortical tissue and cell walls of calcium in filtrated 'Golden Delicious' apples during storage. Postharvest Biology and Technology, 28: 97-111. DOI: $10.1016 / \mathrm{S} 0925-5214(02) 00139-4$

Dixon, R. and Paiva, N., 1995: Stress-induced phenylpropanoid metabolism. Plant Cell, 7: 10851097. DOI: $10.1105 /$ tpc.7.7.1085

Feucht, W., Treutter, D. and Schwalb, P., 1998: Principles of barrier formation of scab infected fruits. Zeitschrift für Pflanzenkrankheiten und Pflanzenschutz, 105, 4: 394-403.

Gosch, C., Halbwirth, H. and Stich, K., 2010: Phloridzin: biosynthesis, distribution and physiological relevance in plants. Phytochemistry, 71: 838-843. DOI: 10.1016/j.phytochem.2010.03.003

Hrazdina, G., Borejsza-Wysocki, W. and Lester, C., 1997: Phytoalexin production in an apple cultivar resistant to Venturia inaequalis. Phytopathology, 87: 868-876. DOI: 10.1094/PHYTO.1997.87.8.868

Lattanzio, V., Lattanzio, V.M.T. and Cardinali, A., 2006: Role of phenolics in the resistance mechanisms of plants against fungal pathogens and insects. In: Imperato F, ed. Phytochemistry: Advances in Research, Research Signpost: Trivandrum, India, 23-67.

Lattanzio, V., Kroon, P. A., Quideau, S. and Treutter, D. (2008) Plant Phenolics - Secondary Metabolites with Diverse Functions, in Recent Advances in Polyphenol Research, Volume 1 (eds F. Daayf and V. Lattanzio), Wiley-Blackwell, Oxford, UK

Leser, C. and Treutter, D., 2005: Effect of nitrogen supply on growth content of phenolic compounds and pathogen (scab) resistance of apple trees. Physiologia Plantarum, 123: 49-56. DOI: 10.1111/j.1399-3054.2004.00427.x
MacHardy, W.E. 1996: Apple scab, biology, epidemiology, and management. APS St Paul Minn, USA.

Martini, S., D'Addario, C., Colacevich, A., Focardi, S., Borghini, F., Santucci, A., Figura, N. and Rossi, C., 2009: Antimicrobial activity against Helicobacter pylori strains and antioxidant properties of blackberry leaves (Rubus ulmifolius) and isolated compounds. International journal of antimicrobial agents, $\quad 34, \quad 1: \quad 50-59$. DOI: 10.1016/j.jjantimicag.2009.01.010

Maurya, S., Singh, R., Singh, D.P., Singh, H.B., Srivastava, J.S. and Singh, U.P., 2007: Phenolic compounds of Sorghum vulgare in response to Sclerotium rolfsii infection. Journal of Plant Interactions, 2 : $25-29 . \quad$ DOI: $10.1080 / 17429140701422504$

Mayr, U., Michalek, S., Treutter, D. and Feucht, W., 1997: Phenolic compounds of apple and their relationship to scab resistance. Journal of Phytopathology, 145: 69-75. DOI: 10.1111/j.14390434.1997.tb00366.x

Mikulič-Petkovšek, M., Štampar, F. and Veberič, R., 2008: Increased phenolic content in apple leaves infected with the apple scab pathogen. Journal of Plant Pathology, 90: 49-55.

Mikulič-Petkovšek, M., Štampar, F. and Veberič, R., 2009: Accumulation of phenolic compounds in apple in response to infection by the scab pathogen, Venturia inaequalis. Physiological and Molecular Plant Pathology, 74: 60-67. DOI: 10.1016/j.pmpp.2009.09.003

Mikulič-Petkovšek, M., Slatnar, A., Štampar, F. and Veberič, R. 2011: Phenolic compounds in apple leaves after infection with apple scab. Biologia Plantarum, 55: 725-30. DOI: 10.1007/s10535-0110176-6

Mikulič-Petkovšek, M., Schmitzer, v., Slatnar, A., Weber, N., Veberič R., Štampar, F., Munda, A. and Koron, D., 2013: Alteration of the content of primary and secondary metabolites in strawberry fruit by Colletotrichum nymphaeae infection. Journal of Agricultural and Food Chemistry, 61, 25: 5987-5995. DOI: $10.1021 / \mathrm{j} f 402105 \mathrm{~g}$ 
Mikulič-Petkovšek, M., Schmitzer, V., Štampar, F., Veberič R. and Koron D., 2014: Changes in phenolic content induced by infection with Didymella applanata and Leptosphaeria coniothyrium, the causal agents of raspberry spur and cane blight. Plant Pathology, 63, 1: 185-192. DOI: $10.1111 /$ ppa.12081

Quave, C.L., Estevez-Carmona, M., Compadre, C.M., Hobby, G., Hendrickson, H., Beenken, K.E. and Smeltzer, M.S., 2012: Ellagic acid derivatives from Rubus ulmifolius inhibit Staphylococcus aureus biofilm formation and improve response to antibiotics. PLoS One, 7: E28737. DOI: 10.1371/journal.pone.0028737

Rusjan, D., Veberič, R. and Mikulič-Petkovšek, M., 2012: The response of phenolic compounds in grapes of the variety 'Chardonnay' (Vitis vinifera L.) to the infection by phytoplasma Bois noir. European Journal of Plant Pathology, 133: 965974. DOI: $10.1007 / \mathrm{s} 10658-012-9967-7$

Russell, W.R., Labat, A., Scobbie, L., Duncan, G.J. and Duthie, G.G., 2009: Phenolic acid content of fruits commonly consumed and locally produced in Scotland. Food Chemistry, 115: 100-104. DOI: 10.1016/j.foodchem.2008.11.086

Sammi, S. and Masud, T., 2009: Effect of different packaging systems on the quality of tomato (Lycopersicon esculentum var. Rio Grande) fruits during storage. International Journal of Food Science and Technology, 44: 918-926. DOI: 10.1111/j.1365-2621.2007.01649.x

Scalbert, A., 1991: Antimicrobial properties of tannins. Phytochemistry, 30: 3875-3883. DOI: 10.1016/0031-9422(91)83426-L

Schovankova, J. and Opatova, H., 2011: Changes in phenols composition and activity of phenylalanineammonia lyase in apples after fungal infections. Horticultural science (Prague), 38: 1-10.

Schwalb, P. and Feucht, W., 1999: Changes in the concentration of phenolic substances in the bark during the annual development of the cherry tree (Prunus avium L.). Advances in Horticultural Science, 13: 71-75.

Scortichini, M. editor. Annual COST 873 Meeting e MCM. Bacterial diseases of Stone fruits and Nuts; 2009. p. 72. Book of Abstracts, 2009 Oct 26-29; Cetara, Italy.

Shirley, B.W., 1996: Flavonoid biosynthesis: 'new' functions for an 'old' pathway. Trends in plant science, 11: 377-382.

Slatnar, A., Mikulič-Petkovšek, M., Halbwirth, H., Štampar, F., Stich, K. and Veberič, R., 2010:
Enzyme activity of the phenylpropanoid pathway as a response to apple scab infection. Annals of Applied Biology, 156: 449-456. DOI: 10.1111/j.1744-7348.2010.00402.x

Slatnar, A., Mikulič-Petkovšek, M., Halbwirth, H., Štampar, F., Stich, K. and Veberič, R., 2012: Polyphenol metabolism of developing apple skin of a scab resistant and a susceptible apple cultivar. Trees - Structure and Function, 26: 109-119.

Solar, A., Dreo, T., Mikulič-Petkovšek, M., Likozar, A., Suštaršič, M., Veberič, R., Matičič, L., Ravnikar, M. and Stampar, F., 2009: Phenolic compounds as potential markers for walnut blight resistance. COST 873 Annual Meeting of working groups 1, 2, 3 and 4. Cetara (SA), Italy. Available from:http://www.cost873.ch/_uploads/_files/ASolar _Walnut-Phenolics_Italy.pdf

Solar, A., Jakopič, J., Veberič R. and Štampar F., 2012: Correlation between Xanthomonas arboricola pv. juglandis severity and endogenous juglone and phenolic acids in walnut. Journal of Plant Pathology, 94, 1: 229-235.

Strack D., 1997: Phenolic metabolism. In: Dey P.M. Harborne J.B. (eds). Plant Biochemistry, pp. 387416. Academic Press, London, UK. DOI: 10.1016/b978-012214674-9/50011-4

Treutter, D. and Feucht, W., 1990: Accumulation of flavan-3-ols in fungus-infected leaves of Rosaceae. Zeitschrift für Pflanzenkrankheiten und Pflanzenschutz, 97: 634-641.

Treutter, D., 2006: Significance of flavonoids in plant resistance: a review. Environmental Chemistry Letters, 4: 147-57. DOI: 10.1007/s10311-0060068-8

Usenik, V., Mikulič-Petkovšek M., Solar, A. and Stampar, F., 2004: Flavonols of leaves in relation to apple scab resistance. Zeitschrift für Pflanzenkrankheiten and Pflanzenschutz, 111: 137144.

Veluri, R., Weir, T.L., Bais, H.P., Termitz, F.R.S. and Ivanco, J.M.V., 2004: Phytotoxic and antimicrobial activities of catechin derivatives. Journal of Agricultural and Food Chemistry, 52: 1077-1082. DOI: $10.1021 /$ jf030653+

Zhou, L.G., Li, D., Jiang, W.B., Qin, Z.Z., Zhao, S., Qiu, M.H. and Wu, J.Y., 2007: Two ellagic acid glycosides from Gleditsia sinensis Lam. with antifungal activity on Magnaporthe grisea. Natural product research, 21: 303-309. DOI: 10.1080/14786410701192702

Acta agriculturae Slovenica, 107 - 1, marec 2016 